\title{
Quarries of the Kunów surroundings as future geotourist attractions within the Kamienna Valley Geopark
}

\author{
Elżbieta Gałka \\ AGH University of Science and Technology, Faculty of Geology, Geophysics and Environment Protection, \\ al. Mickiewicza 30, 30-059 Kraków, \\ e-mail:egalka@agh.edu.pl
}
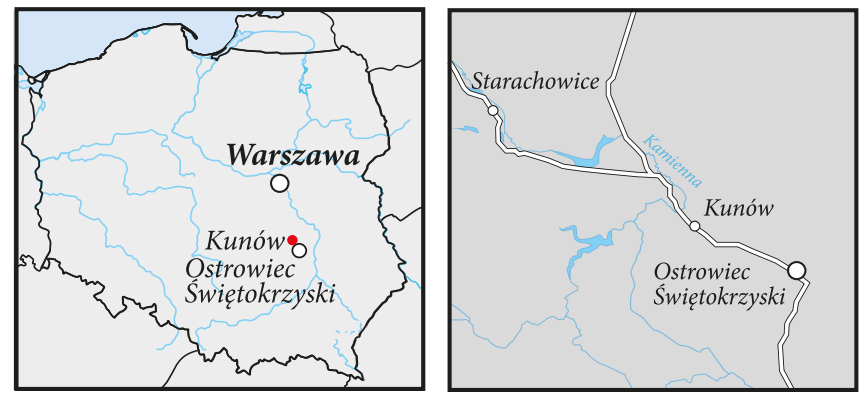

Abstract: In this paper, Liassic and Triassic sandstone quarries of the Kunów surroundings were described as future geotourist attractions within the planned Kamienna Valley Geopark. The history of sandstone excavation from medieval ages to the contemporary period and their usage in regional/local, sacral, monumental, defense as well as industrial architecture were included. Representative, geological, geomorphological and tourist attractions of the quarries and their surroundings were described, marked out and connected in order to create valuable educational and landscape geotourist trail. After implementation of the proper tourist infrastructure, especially accommodation, as well as undertaking marketing efforts in order to promote the centuries-old quarrying centre, Kunów has a chance to become another, besides Jura Park Baltów and Krzemionki flint mine, very important geoeducational and recreational centre within the north-eastern margin of the Holy Cross Mts.

Key words: Kunów sandstone quarries, ancient mining, geological heritage, geotourist attractions, the Kamienna river valley, loess relief

\section{Introduction}

The northern part of the Świętokrzyskie Voivodeship region was during the last several centuries the most important area of sandstone exploitation in the middle of Poland (Urban, Gągol, 1994). Along the Kamienna river valley, since the Middle Ages, the Kunów quarries played the most significant role. Thanks to good technical properties, sandstone rocks were universally used in everyday life, local and regional, monumental and sacral architecture. Whetstones, for instance, played a large role in national production as well as being an export product. In the $18^{\text {th }}$ century, in the reign of King Stanisław August Poniatowski, stones were transported on carts to Piotrawin situated by the Vistula river, and further on, on ships, to Warsaw (Bastrzykowski, 1939). The golden age of the Kunów quarries gradually decreased in the second half of the $19^{\text {th }}$ century. After WWII, the quarries in Kunów were disused and now the old approach roads are hidden among afforested blocks of sandstone. The evidence of historical excavation are man-made, high vertical outcrops with easily visible beds and steps. Simultaneously with Kunów sandstone exploitation in the $17^{\text {th }}$ century, the quarry in Doły Biskupie (Witulin) started to develop. After WWII this quarry was also disused. The quarry in Nietulisko has been active with short breaks until present day.

The ancient and contemporary mining in the Kunów surroundings now has a chance to become one of the most important geotourist attractions within the Kamienna Valley Geopark as proposed by Pieńkowski (2008). Sandstone quarries of the Kunów surroundings occur close to the intersection of three tourist trails. Blue trail for walkers starts at The Holy Cross (Świętokrzyski National Park), runs through Nowa Słupia, Grzegorzewice, the sanctuary of Our Lady and water reservoir in Kałków, Witulin, Nietulisko, Kunów, Archeological Museum and Reserve at Krzemionki flint mine, Jura Park Bałtów and finishes in Pętkowice. The bicycle route connects monuments of the Old Polish Industrial District along the Kamienna river, from Skarżysko-Kamienna to Ostrowiec Świętokrzyski. Another bicycle route is named after Witold Gombrowicz. Good promotion and practical land development taking into account tourist and local inhabitants needs will help to revive forgotten, very precious historical centres of stone mining.

The main objective of this paper is to show the geodiversity and geological heritage of the Kunów surroundings in order to create a geoeducational centre representing ancient sandstone exploitation.

\section{Study area}

The area under investigation is situated on the northern margin of the Holy Cross Mts, in the northern part of the Opatów - Sandomierz loess cover, and in the marginal zone of the Kamienna valley (Jersak, 1977). The Kunów region lies on the border line of two Kielce Upland mesoregions distinguished by Kondracki (2001): Sandomierz Upland and Iłża Foreland. The study area encompasses loess valleys of the Kunów region: Ciołek, Stawiska and Świślina river region. 


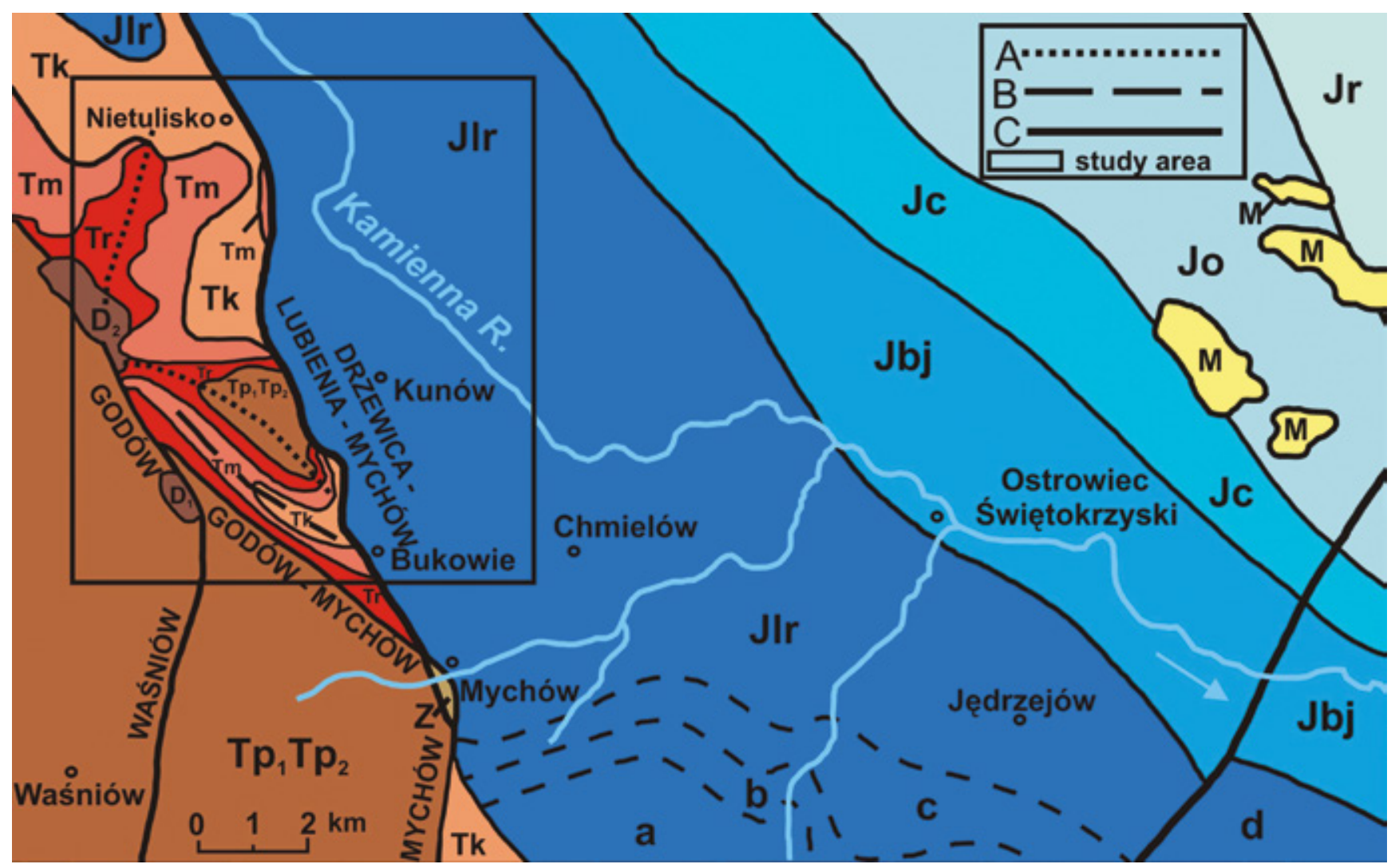

Fig. 1. Extent of the study area on the background of the geological map with tectonic elements. Source: Kosmowska-Suffczyńska (1966), changed: A - elevations, B - depressions, C - dislocation lines, D1 - Lower Devonian, D2 - Middle Devonian, Z - Zechstein, Tp1 - Tp2 Bunter Sandstone, Tr - Rhaetian, Tm - Shell Limestone, Tk - Keuper, Jlr - Liassic (a - Zagaje level, b - Gromadzice level, c - Zarzecze level, d - Ostrowiec level), Jbj - Bajocian, Bathonian, Jc - Callovian, Jo - Oxfordian, Jr - Rauracian, M - Miocene land deposits

The region consists of two principal parts: Paleozoic Core and the Permian - Mesozoic Marginal Zone (Fig. 1). The area under investigation lies within northern Łysogóry - Radom Unit in the marginal zone of the East - European platform (Urban, Gągol, 2008). The bedrock of the Pleistocene and Holocene sediments is built of the Liassic and Triassic sandstones and siltstones, excavated in the Kunów region since 12 th century.

\section{Kunów, Nietulisko and Witulin sandstone quarries - topography and geological properties}

The recent topography of the Kunów surroundings is typical for loess relief. Within the Kamienna valley escarpment zone, the average thickness of the loess cover is $12 \mathrm{~m}$ (Jersak, 1965). The Kunów region has a wavy appearance strongly cut by dry valleys and gullies and is located at an altitude of 180 $280 \mathrm{~m}$ a.s.l (Bukowska Mountain $277 \mathrm{~m}$ a.s.l.). A dense net of young erosion ravines is the result of the low erosion base of the Kamienna river valley (180 $\mathrm{m}$ a.s.l.) and to its side, the Ciołek and the Stawiska, valleys (190 m a.s.l.). Steep slopes and a 40-60 m relative height triggered forming of the anthropogenic terraces. In some places we can distinguish over 20 levels of these loess mesoforms along the slope. Another typical example of anthropogenic loess relief are road gullies. Below the loess cover, Jurassic and Triassic sandstones and siltstones occur and are hidden in the dense net of ravines.

Kunów sandstones are concentrated in the vicinity of the south of the Kunów town. High, vertical outcrops (beds) are easily visible along the Udziców Dolny - Kunów road on the right side of the Kamienna River valley. In the middle part of the Grabutka valley, within Bukowska Mountain and Gródek Hill, there occur, in the form of afforested, disused, quarries, outcrops and stony steps (from the middle of $19^{\text {th }}$ century). Bigger, probably younger excavations are concentrated in the Parzyński ravine between hills. Stretching for several hundred meters, shallower quarries of sandstone on the north and west side of Bukowska Mountain seem to be the oldest region under exploitation (Urban, Gągol, 1994) (Fig. 2). In the Ciołek valley and Udziców ravine they occur in the form of outcrops or stony steps. In Biskupie Doły, they occupy sides of the Świślina river. The quarry in Doły Biskupie (Witulin) is a side excavation $300 \mathrm{~m}$ long and $20 \mathrm{~m}$ high.

Kunów sandstones in Bukowska Mountain are white, light grey and yellowish, cream coloured with iron dripstones, fine and medium grained with siliceous binding material. They occur in the form of fine, medium or coarse beds. Kunów sandstones of the Early Jurassic Age (Toarcian) are inshore (lagoonal) sediments, from shallow and quiet bodies of water. They are characterized by good block properties: the thickness of the beds can be several meters. 


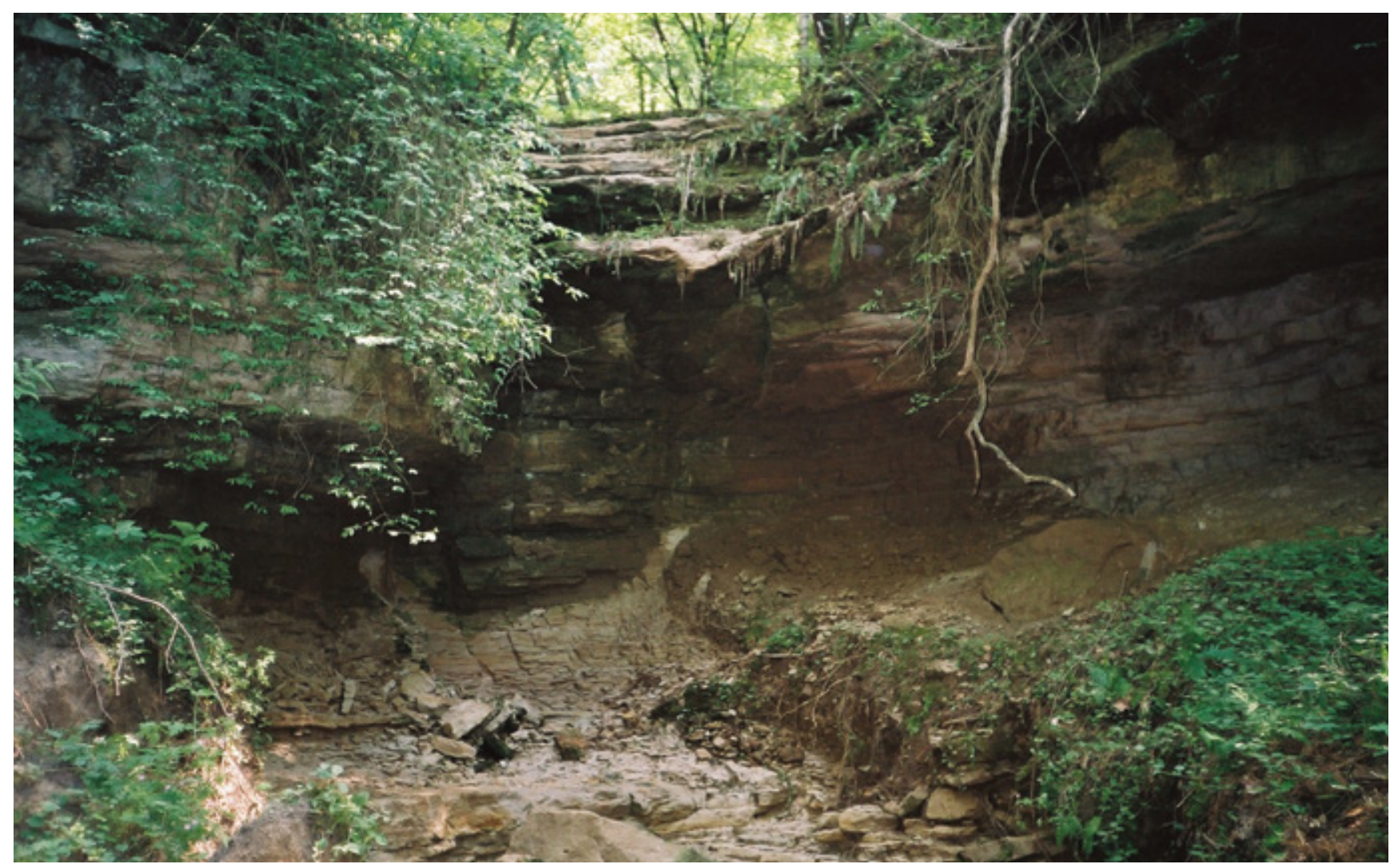

Fig. 2. Old side quarry occurring within Bukowska Góra, photo E. Gałka

Kunów sandstones have good technical qualities, are easy to process, exploit, and have good resistance to atmospheric influence. Sandstones in Nietulisko are similar but have clayey material binding.

Sandstones from Doły Biskupie (called Witulin sandstones) are older, they are light-cream colored and represent the higher part of the Upper Triassic Age (Rhaetian). They are medium grained and are quite easy to process. Sandstones from Doły Biskupie are sea, inshore sediments arisen in shallow waving waters (Urban, Gagol, 2009).

\section{Kunów sandstones \\ in everyday life and regional or local architecture - selected examples}

From the very beginning, i.e. from the Middle Ages, throughout centuries, until the first half of the $20^{\text {th }}$ century, excavated sandstones were used in querns, millstones, grinding wheels and whetstone production (Urban, Gągol, 1994). Later Kunów sandstones, thanks to good abrasion, were regularly used in construction as material for columns, sculptures and decorative elements of facades. Since the onset of $12^{\text {th }}$ century, many stony richly ornamented churches appeared, for instance the Benedictine monastery of the Holy Cross and the Romanian Saint Martin Collegiate Church in Opatów (Bastrzykowski, 1939).

In 1430, north-east of Kunów, on the borderline between the Kunów and Iłża demesnes, a gothic Saint Katherine chap- el, funded by Bishop Zbigniew Oleśnicki is now the oldest free standing chapel in Poland. The famous sculpture of Saint Emeric in Nowa Słupia is also made from Kunów sandstone.

The growth of intensive sandstone exploitation in the $16^{\text {th }}$ century was connected with the construction of Renaissance residential and the Baroque church buildings. Sandstones were exploited for modern black-and-white combinations (Sygietyńska, 1978). Rocks excavated in the $16^{\text {th }}-17^{\text {th }}$ century in Bukowska Mountain and Biskupie Doły quarries attracted many sculptors to Kunów, including among others, from Germany, Italy and Moravia (Bastrzykowski, 1939).

In the 17 th century, the Krzyżtopór Castle in Ujazd was built, where $300 \mathrm{~m}^{3}$ Kunów sandstone was used to build the wall and the Castle's main symbols: cross and battleaxe. In 1683, for the first time in Poland, the street chapel of the Godly Mother Passowska was placed in the Krakowskie Przedmieście street; also the façade of the Discalced Carmelites church in the Royal Route in Warsaw is made from the famous sandstone (Jarmontowicz et al., 1994).

The quarrying boom fell in the 18th and 19th centuries. In 1787, quarries in Kunów were visited by Polish king Stanisław August Poniatowski. He placed an order for figures, monuments and architectural details for buildings raised at that time in Warsaw, for instance: the Łazienki Palace. In 1830, sandstone was used to build the National Theatre in Warsaw (Antonio Carazii) (Bastrzykowski, 1939; Miks-Rudkowska, 1973). In 1834-1836, the Potocki grave was built by Henryk Marconi (Jarmontowicz et al., 1994). 


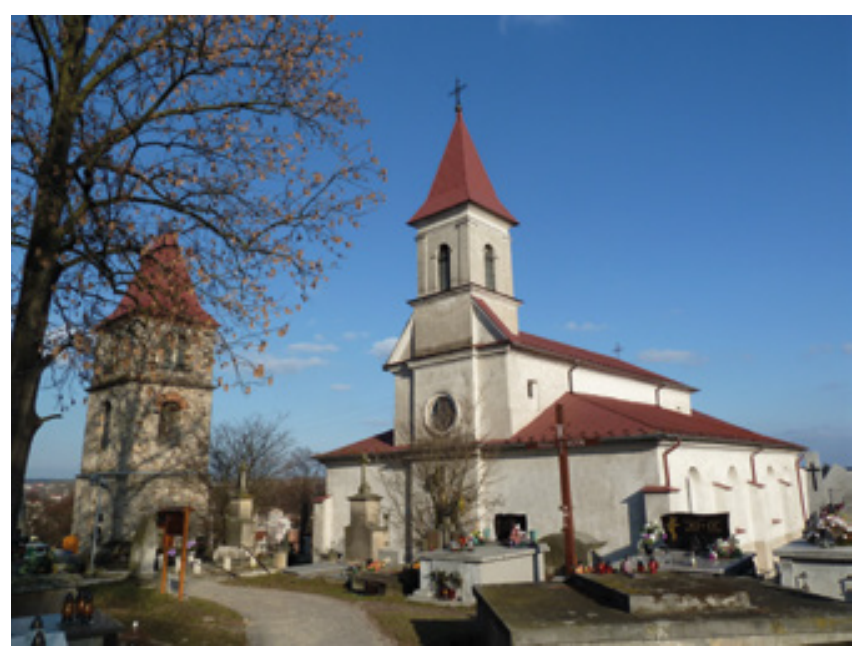

Fig. 3. Historical St Władysław church, bell tower and graveyard in Kunów, photo E. Gałka

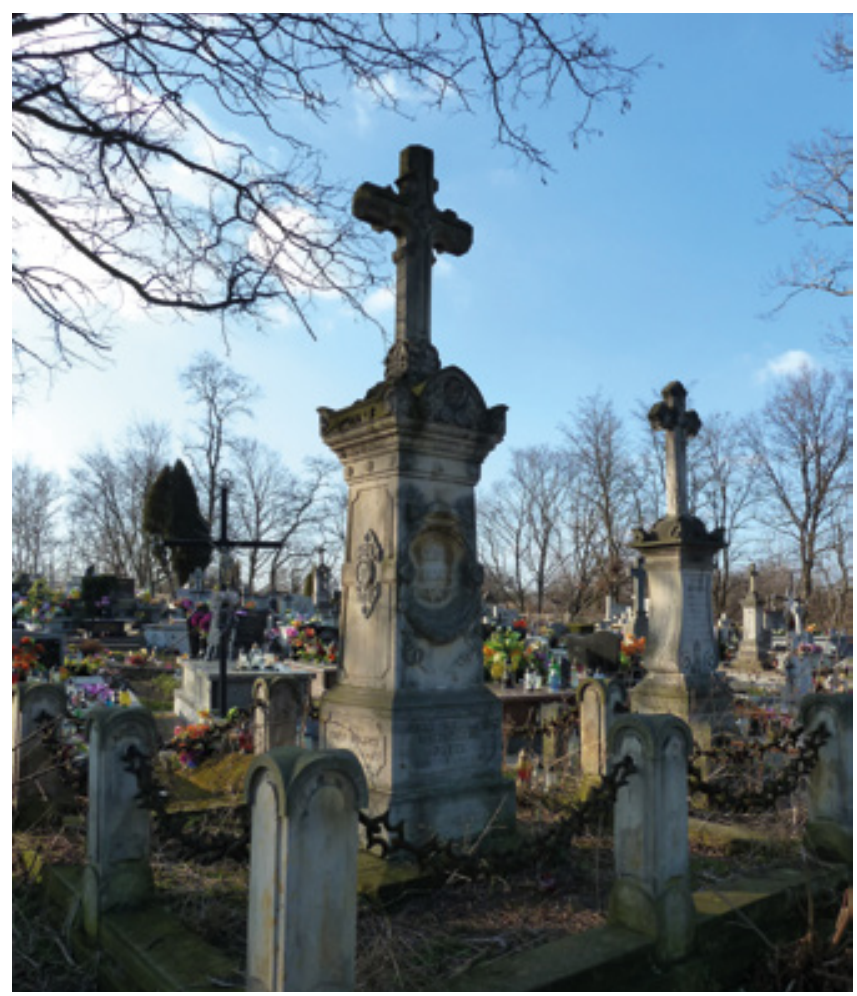

Fig. 5. Historical monument in the graveyard in Kunów, photo E. Gałka

In the $19^{\text {th }}$ century, in Kunów and Doły Biskupie, sandstone excavation was connected with the Old Polish Industrial District development along the Kamienna river valley. Defensive building development in Poland was the second reason for lager demand for sandstones during this period (fortresses in Dęblin and Modlin) (Fudalewski, 1900; Bastrzykowski, 1939).

In the second half of the $19^{\text {th }}$ century, after the collapse of the January Uprising and the construction, in 1885, of the railway line Dąbrowa Górnicza - Dęblin next to the Szydłowiec mining centre, Kunów sandstones were exported to different regions of the Kingdom of Poland and Russia but the role of Kunów gradually decreased.

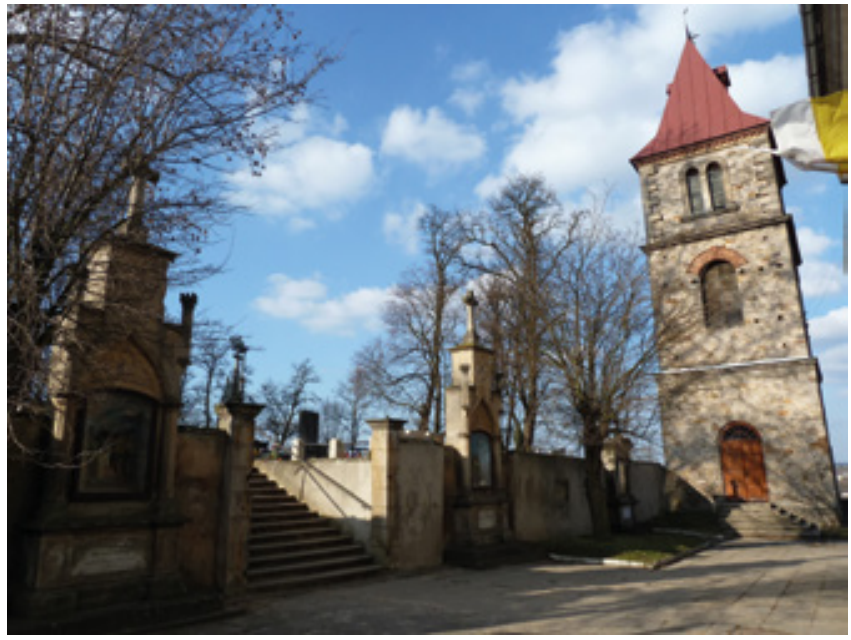

Fig. 4. Sandstone walls with gates and the Stations of the Cross around the St Władysław church, photo E. Gałka

Sandstones from Biskupie Doły (Witulin) were exploited since the beginning of the $17^{\text {th }}$ century. In the first half of the $19^{\text {th }}$ century they were used for the Kamienna river regulation and as a building material for the Nietulisko rolling mill funded by Stanisław Staszic (destroyed by flood in 1903). In 1895, next to the described quarry in Doły Biskupie, Ignacy Kotkowski - grandfather of the famous Witold Gombrowicz, founded a stone factory and started to exploit sandstones. After his death, since 1911 his work was continued by the parents of Gombrowicz. Apart from the quarry, a famous complex of historical buildings, watermills, paper mill and cardboard factory was built. When visiting famous Jagiellonian Library in Cracow, please note that it was made of sandstones from Biskupie Doły (Kamieński, Skalmowski, 1957). After WWII the quarry was disused.

After WWII, the continuously state-owned quarries in Nietulisko played the most important active role. Sandstones were used as elevation material for Warsaw's destroyed Old Town and Warsaw's Palace of Culture and Science also built at that time, as well as ripraps for MDM estate and the $\mathrm{W}-\mathrm{Z}$ route. In 1992, two years after privatization, deposit excavation became unprofitable, and the Nietulisko quarry was closed. As for the Nietulisko quarry called "Jurassic Sandstones Nietulisko 1 Mine", in 2007, its new owners, Marek Łucki and Konrad Trojanowski, took up the exploitation of the sandstone blocks in the northern and eastern part of the deposit. Sandstone is being processed into small fragments, called ripraps, close to the excavation site, for example for the purpose of wall construction. Permission for deposit excavation provides for the possibility of exploitation of $1000 \mathrm{~m}^{3}$ annually. Owners of the quarry are planning to construct a new production hall and broaden their production assortment (Kowalska, Kowalski, 2010).

Centuries-old sculpting tradition left behind many traces in Kunów and its surroundings and occurs in various forms; locks on the Kamienna river, beautiful figures, sculptures, monuments on the graveyards in Kunów, Ćmielów and Wszechświęte, in parks, and other places within the whole area. Sandstones were also used to make thresholds, stairs or windows and doors' decorative frames. The most precious sand- 
stone monument is St Władysław Church, which was erected in 1638. The most famous sandstone elements in this church are: the altar of Transfiguration of Jesus from 1850 to the design of Franciszek Kacper Fornalski, and made by Jan Wilczyński, St Wojciech and St Stanisław figures made by Antoni Kłosiński in 1867, and the sandstone floor funded by stoneworker Ignacy Kotkowski in $19^{\text {th }}$ century. In 1896 , the famous Polish painter and architect, professor Wojciech Gerson designed a bell tower, which was built next to the Kunów church and graveyard (Fig. 3). His daughter, Gersonówna, became the most famous woman who carved sculptures in sandstone in Kunów at the turn of the $20^{\text {th }}$ century. Her most famous sculpture is a nativity play (bow of the Three Wise Men) under the altar of the Mother of God. Around the church, stony walls with gates and the Stations of the Cross were made (Fig. 4).

In the Town of Kunów two restored sandstone monuments stand in the renovated marketplace. The Saint Jan Nepomucen figure from 1755 is situated by the river, and many monuments and figures can be found along the roads or at the intersections of the old trading routes.

In the graveyard in Kunów, there are over 200 sandstone monuments and figures of historic value (Fig. 5). It is one of the oldest graveyards in the region. In 2007, it was entered in the national register of historical monuments. One of the oldest figures in the graveyard is the figure of Jesus carrying the cross dating back to 1747 , but the oldest known sandstone figure in the Kunów vicinity is Pieta from 1701, standing in the Nietulisko quarry.

Another, less known graveyard in Wszechświęte, dates from the $19^{\text {th }}$ century. There are many interesting epitaphs engraved on the old monuments. Next to the graveyard there is a gothic church,where Witold Gombrowicz was baptized.

\section{Geological attractions of the Kunów region}

The quarries in Kunów, Doły Biskupie and Nietulisko described above appear within the Landscape Protection Area of the Kamienna River Valley and the Kamienna Valley Geopark as designed by Pieńkowski (2008). Within the Natura 2000 network of protected areas Special Area of Conservation (SAC) "Kunów Hills" was designed. Within the most attractive ravines of the Kunów region, "Bukowska Mountain" and "Udziców", nature reserves were created. In 2010, in the Natura Shadow List, "Kunów Hills" received the status "the area in need of extension".

But already in 1994 Jan Urban and Jerzy Gągol were the first researchers to propose the creation of a new nature reserve within the sides of Bukowska Mountain area together with the Parzyński Ravine (Urban, Gągol, 1994) (Fig. 6).

According to the article mentioned above (Urban, Gągol, 1994), the distribution and pattern of excavations, the relationship between them and the occurrence of sandstone, as well as size and shape of blocks, and location of slag heaps expresses the methodology of geological survey and sandstones exploitation in the $18^{\text {th }}$ and first half of the $19^{\text {th }}$ century.

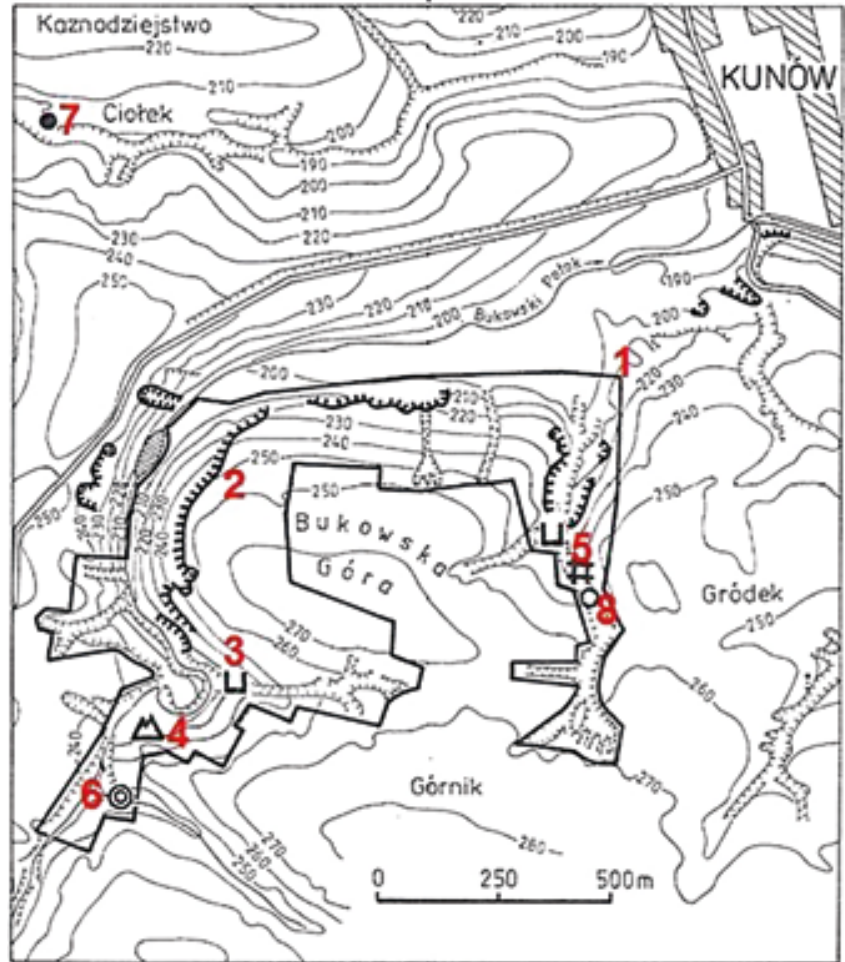

Fig. 6. Nature reserve as designed within Bukowska Mountain. Source: Urban and Gągol (1994): 1 - borders of the designed nature reserve, 2 - Kunów sandstone quarries, 3 - natural steps and thresholds in ravines, 4 - side rocks, 5 - Liassic mudstones outcrop with sphaerosiderites insertions, 6 - condensed Shell-Limestone profile outcrop, 7 - fossil soils and sinters outcrops in loess (Ciołek ravine), 8 - big erratic boulder

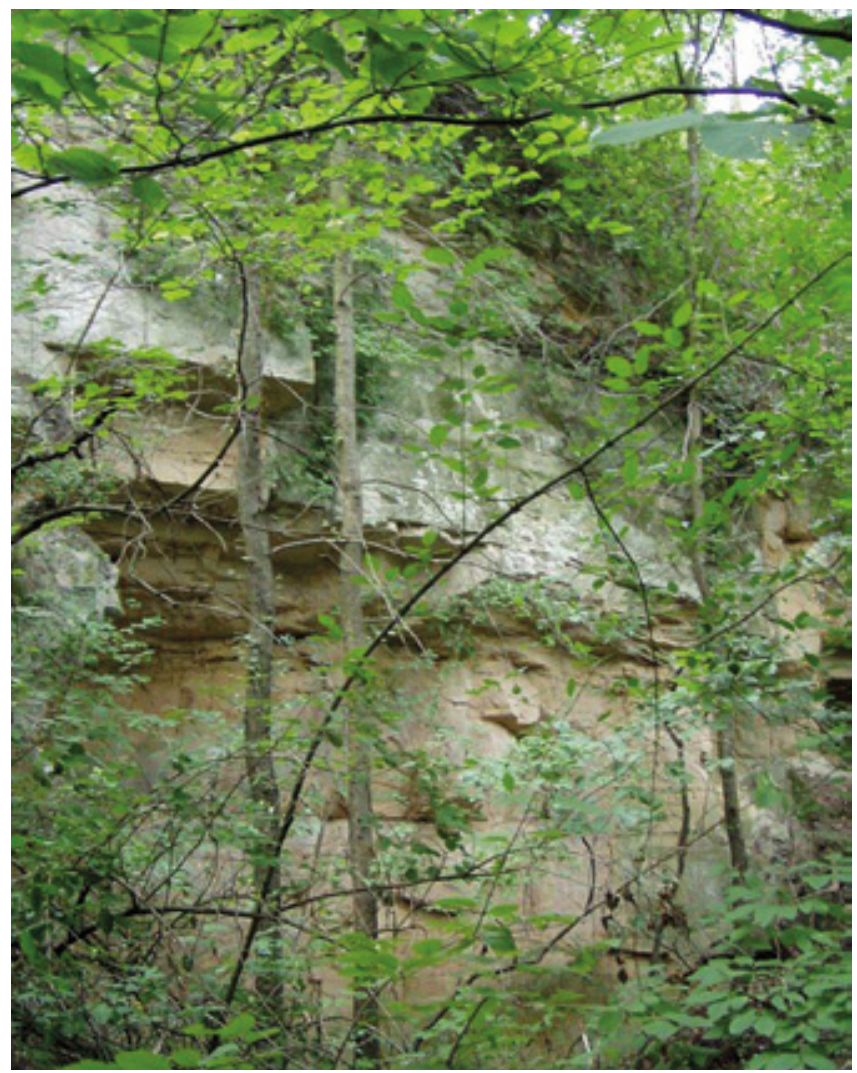

Fig. 7. Sandstone outcrops in the Bukowska Mountain quarry, photo J. Urban (Urban, Gągol, 2009) 


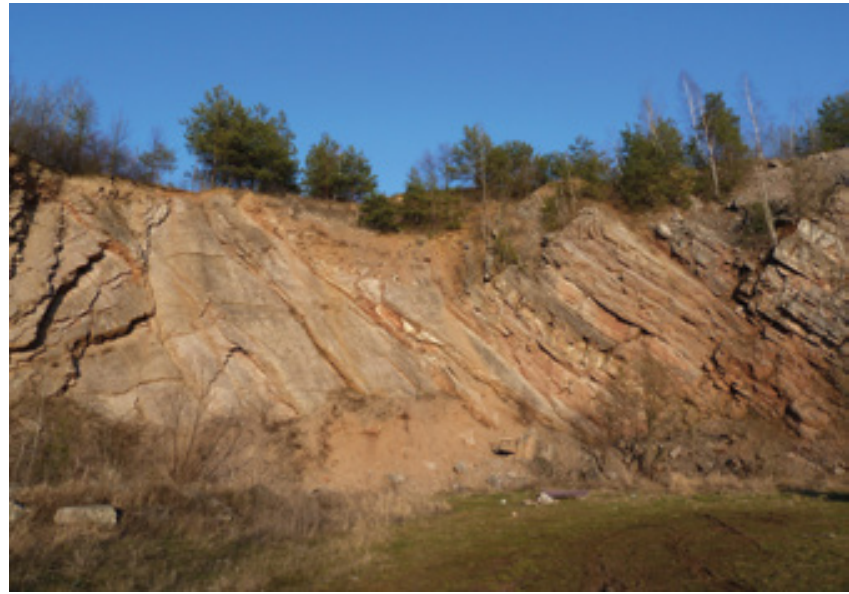

Fig. 8. Doły Opacie Quarry - natural monument, photo E. Gałka

Outcrops enable observation of their lithological properties (sedimentary structures, flora remains). Apart from quarries, natural rocks, sandstone thresholds (in some parts of the ravine forming cascades) and sphaerosiderites occurrence are worth noting (Fig. 7).

South of Bukowska Mountain, there is a fragment of the Drzewica-Lubienia-Mychów dislocation zone worthy of protection because of the strong inclination of the Upper Triassic Age sediments occurring in the natural form of rock. Another is the Bukowie anticline with interesting Rhaetian outcrops and a condensed Shell-Limestone profile providing a chronicle of the history of the Earth. The 240-230 million years interval was recorded within the $20 \mathrm{~m}$ thick geological profile with sandstones, limestones, and marls with fossil fauna - bivalves, brachiopods, ceratites and fish. Zones of the $19^{\text {th }}$ century brown coal survey in the Triassic sediments are also worth noting (Urban, Gągol, 1994). In Udziców Dolny, opposite the Zimny Dó gully, there is also a spring, which is famous in Świętokrzyskie Voivodeship region.

The Świślina river valley with its mountainous character, side rocks and quarries is one of the most beautiful valleys within the north margin of the Sandomierz Upland. In the Biskupie Doły (Witulin) quarry, in the lower part of the wall, coarse beds of Rhaetian sandstones are visible. In the upper part of the wall, there appear complex limestones of the Lower, Middle and the lowest part of The Upper Shell Limestone. Since 1987 this quarry has been protected as a natural monument. Apart from the quarry itself, the technical expertise connected with exploitation and sandstone processing are also essential (Urban, Gągol, 1994).

In the Świślina river valley, there is also one very important geological quarry in Doły Opacie, disused since 1984 (Fig. 8), in which we can see a structural contact between the Middle Devonian dolomites and the Lower Triassic sandstone rocks (Wariscian discordance, one of the third in the Holy Cross Mts. region, similar as in the case of the famous for tetrapod traces Zachełmie). Since 1987 this quarry has been protected as a natural monument. Nearby in Wióry we can find traces of the Triassic vertebrates (Urban, 1990).

In close vicinity of this area occurs the "Rocks in Krynki" nature reserve. The main tourist attraction are natural outcrops of the Lower Triassic sandstone rocks (river sediments) which occur in the form of: stony ravines, caves, blocks, thresholds, bluffs, ledges, overhangs and mushroom rocks.

\section{Kunów quarries as future geotourist attractions}

The quarries described above, which are localized within the borders of the planned Geopark Kamienna Valley, have a chance to become a valuable geotourist product of the Kunów surroundings. At present, due to disappearance of some geosites and their scientific and educational functions as a result of natural plant succession, this area has become inaccessible to ordinary tourists. That is why in order to better promote the geodiversity and geological heritage related to the ancient metallurgy of the Kunów surroundings, it is important to do appropriate research and marketing activities to ensure interest in these future (geo)tourist objects.

The quarries of the Kunów surroundings are important geoeducational objects, that is why, geotourist boards explaining particular geosites should be created with additional information about biodiversity of the Kunów Hills and Pleistocene/ Holocene stratigraphy (Fig. 9) on the following geotourist trail: Kunów - Bukowska Mountain - Prawęcin - Doły Opacie - Doły Biskupie - Nietulisko Duże - Nietulisko Małe - Kunów - Krynki (facultative site). It is essential that not only geological heritage, history, ways of sandstone excavating, but also loess relief, fossil soils and flora/fauna species of the Kunów region are popularized. This proposed trail throughout its length would overlapp with the tourist trails described above.

These quarries will constitute a very good way of geotourism promotion. Apart from school excursions on consecutive stages of school education, these objects could also become an obligatory point as part of regional student training within the Holy Cross Mts. and its margin (geological, geomorfological, tourist) including „Tourist attractions of Poland - The Holly Cross Mts." which is carried out by students of AGH. The occurrence of the said geotourist attractions within protected areas is also an excellent chance of promotion of sustainable tourism in the society.

In order to open the quarries to the public it is necessary to build the tourist infrastructure from scratch. According to the previous short-term and current long-term (2011-2020) program of the revival of the Kunów town, Bukowska Mountain will be adapted for local inhabitants and tourist needs. The project comprises: ski lift, ski (snowboard), walk and bicycle routes, as well as routes for pedestrians, approach roads, car parks, football pitches, tennis court, camp places.

Within this quarry, as part of the so-called "small retention", modernization is planned of the body of water on the Garbutka river and its surroundings. During the flood which occurred on 23 May 2007, after heavy rainstorm, the dam was destroyed. It needs restoration in order to be used as a flood-control reservoir and for angling purposes. A rope park will also be a big tourist attraction. 


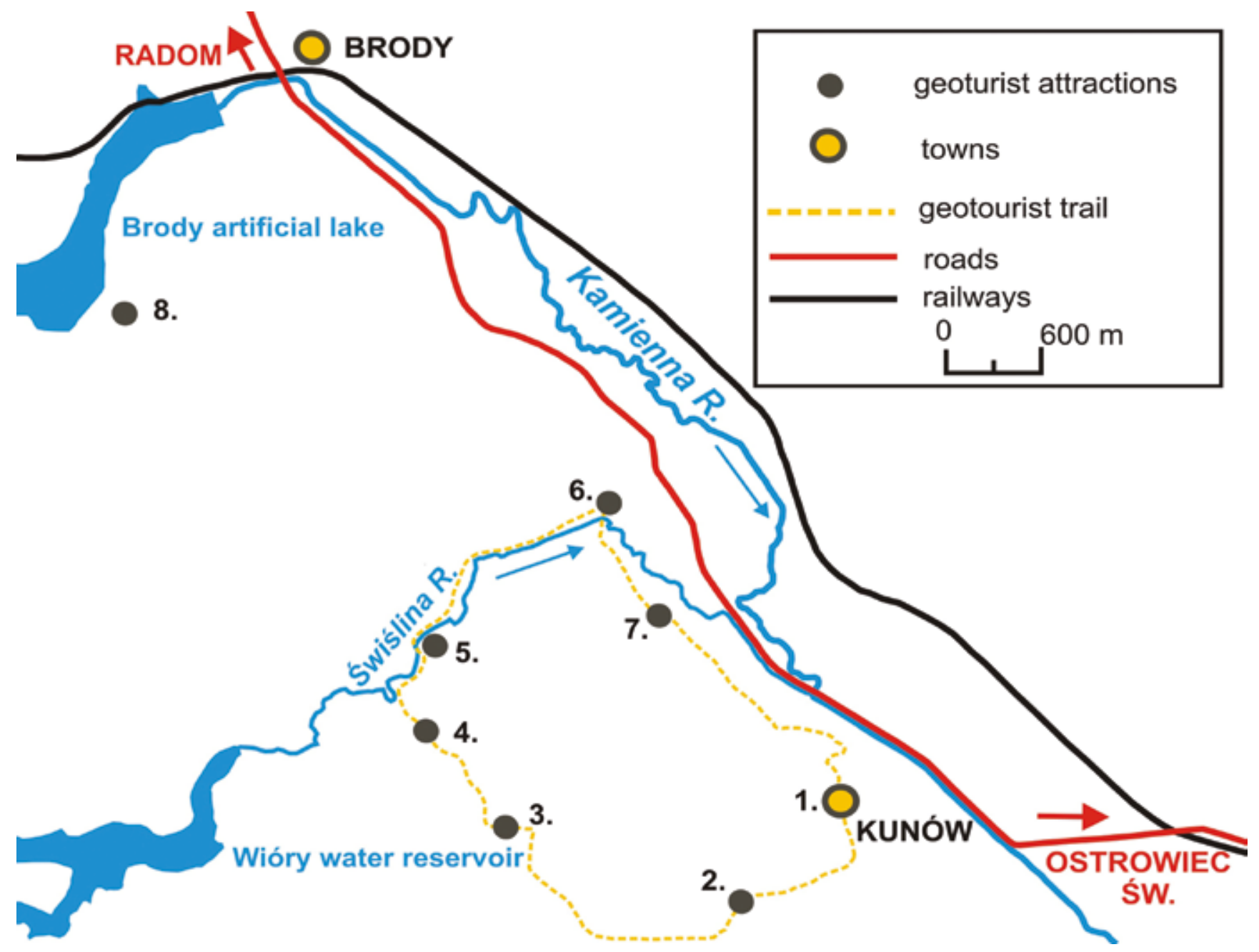

Fig. 9. Proposed geoturist trail: 1. Kunów Town, 2. Bukowska Mountain quarry, 3. Prawęcin view point, 4. Doły Opacie Quarry - natural monument, 5. Quarry and buildings of Gombrowicz cardboard factory in Biskupie Doły, 6. Ruins of the old rolling mill in Nietulisko Duże, 7. Sandstone quarry in Nietulisko, 8. Rocks in Krynki nature reserve

For a better overall view of the Landscape Protection Area of the Kamienna River Valley, including the Bukowska Mountain quarry and the loess landscape of the Kunów surroundings, a properly secured area with viewpoints and safety barriers on the east and west sides of the Bukowska Mountain quarry should be created. There are also plans for opening a Centre of Quarrying in the old granary in Kunów or in the rolling mill in Nietulisko Duże. Apart from static exhibitions connected with the technique of Kunów sandstone mining and processing, the multifunctional halls including multimedia and outside exhibitions could also be of interest. The exhibitions could be connected with the open air sculpture workshops. In Nietulisko Duże, besides open air sculpture exhibitions within an old rolling mill area (Fig. 10), establishing Tourist Recreation Centre, restoration of old water ways and filling a water tank dome for the purpose of creating a safe recreational pool is planned. An old warehouse building will be converted into a hall. The area will be arranged to include tennis courts, car parks and football pitches.

There is also a plan of reconstruction of the remains of the stony workshop in Doły Biskupie dating from 1885 (the potential place of sculpture exhibitions in the open air, a craft exhibition, museum in the director's house).

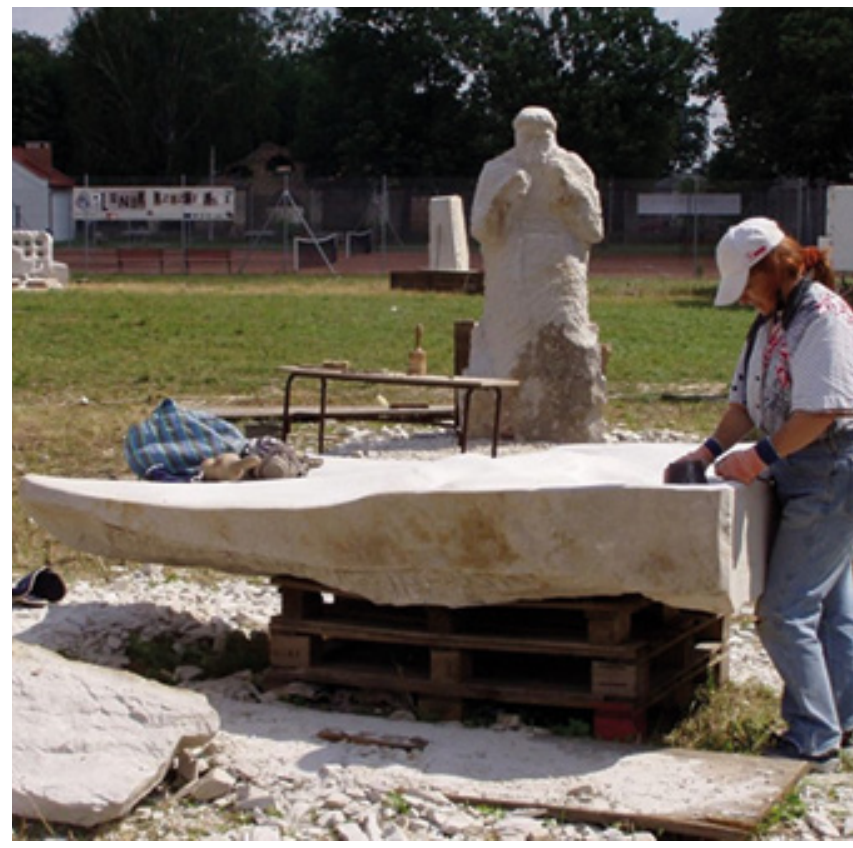

Fig. 10. Open air sculpture workshops in Nietulisko Duże, photo J. Urban (Urban, Gągol, 2009) 
Due to high geomorphological and landscape values, the Kunów surroundings have excellent conditions for active tourism development, including various kinds of qualified tourism, such as rock and ice climbing, bouldering, cycling or fishing. Controlled off-road drives within waterlogged valleys and side gullies area provide a good alternative for spending free time.

In the area of Kunów, there are also good conditions for tourist canoeing on the Kamienna river. Similarly to the famous nearby Bałtów Jurassic Park, the construction of a river harbour and delineating of walk and bicycle routes is planned in close vicinity of the Kamienna. Car parks and camp and fire places will be distributed along the Kamienna river.Unfortunately, although the national road nr 9 runs through Kunów, and there is a railway station, tourist base is still underdeveloped. In Kunów and its surroundings, only three agro farms offer active leisure, one road hotel with restaurant in Rudka offers accommodation, and there is one petrol station with a restaurant. Tourist base needs an urgent enhancement.

\section{Summary}

In order for the quarries to be entirely used in geotourism, they should serve at least one of the following purposes: scientific (paleontological, mineralogical, lithological discovery), educational (to have legible geological profiles, legible tectonic elements, sites representing geological formations), visual (well exposed quarry elements in landscape, for instance, walls, outcrops), potential locations (easy access to the site), tourist (interesting beauty spots, water reservoirs, bicycle routes, caves) and recreational (well-prepared places for rest, fishing etc.) (Nita, 2010). After afforested blocks have been cleared, ancient quarries of the Kunów surroundings will meet all natural requirements. Tourist and recreational functions could be fulfilled completely only after realization of the program of the revival of the Kunów district. Then, just as in the case of the nearby Jura Park in Bałtów or flint mine in Krzemionki Archeological Museum and Reserve, good promotion of sandstone traditional mining together with metallurgy centre along the Kamienna river will bring benefits for local inhabitants and tourists.

\section{References}

Bastrzykowski A., 1939. Monografia historyczna Kunowa nad Kamienna i jego okolicy. Kraków.

Fudalewski W., 1900. Kunów nad Kamienna w Powiecie Opatowskim Guberni Radomskiej. Warszawa.

Jarmontowicz A., Krzywobłocka-Laurów R., Lehmann J., 1994. Piaskowiec $w$ zabytkowej architekturze i rzézbie. Biblioteka Towarzystwa Opieki nad Zabytkami. Warszawa.

Jersak J.,1965. Stratygrafia i geneza lessów okolic Kunowa. Acta Geographica Lodziensia 20. Łódź.

Jersak J., 1977. The late pleistocene and holocene deposits in side valleys of the Kunów region. Folia Quaternaria, 49. Kraków.

Kamieński M., Skalmowski, W. (eds) 1957. Kamienie budowlane i drogowe. Wydawnictwa Geologiczne, Warszawa.

Kondracki J., 2001. Geografia regionalna Polski. PWN, Warszawa.

Kosmowska-Suffczyńska D., 1966. Rozwój rzeźby w trzeciorzędzie okolic Ostrowca Świętokrzyskiego i Ćmielowa. Prace Geograficzne, 54: 1-114.

Kowalska M., Kowalski K., 2010. Historia kamieniołomów i kamieniarstwa na Ziemi Kunowskiej. In: Brociek W. R. (ed.), Tradycje i dziedzictwo przemysłowe na Ziemi Ostrowieckiej. Materiały z sesji Europejskich Dni Dziedzictwa 17-18 września 2010 r. Ostrowiec Świętokrzyski, 88-95.
Miks-Rudkowska N., 1973. Rzemiosło kamieniarskie Kielecczyzny (zarys historyczny). In: Kowecka E. (ed.), Z dziejów rzemiosła w Kielecczyźnie. Kielce.

Nita J., 2010. Quarries in landscape and geotourism. In: Krajobraz a turystyka. Prace Komisji Krajobrazu Kulturowego Nr 14: 243-251. Komisja Krajobrazu Kulturowego PTG, Sosnowiec.

Pieńkowski G., 2008. The Kamienna Valley Geopark - more than dinosaurs. Geological Review, 56: 629-638.

Sygietyńska H., 1978. Kamień $w$ architekturze i rzé́bie Warszawy. PWN, Warszawa.

Urban J., 1990. Ochrona obiektów przyrody nieożywionej w Krainie Gór Świętokrzyskich, Rocznik Świętokrzyski, 17: 47-78.

Urban J., Gągol J., 1994. Quarries of sandstones in ancient centres of stone mining in the northern part of the Holy Cross region (central Poland) as monuments of engineering and nature. Geological Review, 42: 193-200.

Urban J., Gągol J., 2008. Geological heritage of the Świętokrzyskie (Holy Cross) Mountains (Central Poland). Geological Review, 56: 618-628.

Urban J., Gągol J., 2009. Dzieje eksploatacji piaskowców kunowskich i dolskich - świadectwa historyczne i przyrodnicze. Materiały z konferencji „Kamień w budownictwie” wygłoszonej w dniu 17.042009 r. w ramach targów INTERKAMIEŃ w Kielcach, 1-36. 